\title{
KETEPATAN DALAM MENEGAKKAN DIAGNOSA KEPERAWATAN GUNA TERCAPAINYA INTERVENSI KEPERAWATAN YANG BERKUALITAS
}

\author{
Elisa Claudia Simanjuntak / 181101114 \\ elclaudia02@gmail.com
}

\begin{abstract}
ABSTRAK
Latar Belakang : Untuk dapat menyembuhkan atau meningkatkan taraf kesehatan pasien, diagnosa yang ditetapkan tentu akan sangat berdampak. Saat ini perawat perlu mengangkat atau menetapkan diagnosa keperawatan yang berorientasi pada upaya tercapainya intervensi keperawatan yang berkualitas.

Tujuan : Tujuan penulisan kajian ini adalah untuk mengetahui pentingnya ketepatan dalam menegakkan diagnosa agar intervensi keperawatan yang akan diberikan berkualitas.

Metode : Metode yang digunakan dalam kajian ini adalah literature review, yaitu dengan cara menganalisis, mengeksplorasi serta mengkaji bebas jurnal dan buku teks yang membahas tentang pentingnya ketepatan dalam menegakkan diagnosa.

Hasil : Hasil kajian menunjukkan bahwa diagnosa merupakan dasar untuk menentukan intervensi keperawatan yang tepat dan berkulitas. Oleh karena itu, diagnosa keperawatan yang dirumuskan atau ditegakkan oleh perawat harus tepat.

Pembahasan : Diagnosa keperawatan adalah proses menganalisis data yang didapatkan melalui proses pengkajian untuk menegakkan diagnosa. Dalam tahap diagnosa, perawat berperan secara independen, artinya perawat dapat merumuskan sendiri diagnosanya, bertanggung jawab terhadap diagnosa yang dirumuskan, membedakan peran perawat dengan peran dokter, serta menunjukkan bahwa asuhan keperawatan tersebut bermutu, mempunyai kualitas, dan atas dasar pendidikan perawat.
\end{abstract}

Kata Kunci : Diagnosa Keperawatan, Intervensi Keperawatan, Berkualitas. 


\section{Latar Belakang}

$\begin{array}{cccc} & \text { Diagnosa } & \text { merupakan tahap } \\ \text { kedua } & \text { dari } & \text { rangkaian } & \text { proses }\end{array}$ keperawatan setelah pengkajian. Tenaga kesehatan tentu telah mengetahui cara menegakkan atau merumuskan diagnosa. Di rumah sakit, perawat memiliki peran besar terhadap kelangsungan perawatan pasien. Perawat bertugas memberikan asuhan keperawatan yang berkualitas. Pemberian asuhan keperawatan saat ini berfokus kepada cara menyembuhkan penyakit maupun meningkatkan taraf kesehatan pasien. Untuk dapat menyembuhkan atau meningkatkan taraf kesehatan pasien, diagnosa yang ditetapkan tentu akan sangat berdampak. Saat ini perawat perlu mengangkat atau menetapkan diagnosa keperawatan yang berorientasi pada upaya tercapainya intervensi keperawatan yang berkualitas. Diagnosa keperawatan yang tepat akan menjadi dasar untuk menentukan intervensi keperawatan tersebut bagi pasien.

\section{Tujuan}

Pengkajian ini dilakukan untuk mengetahui pentingnya ketepatan dalam menegakkan diagnosa agar intervensi keperawatan yang akan diberikan berkualitas.

\section{Metode}

Metode yang digunakan dalam kajian ini adalah literature review, yaitu dengan cara menganalisis, mengeksplorasi serta mengkaji bebas jurnal dan buku teks yang membahas tentang pentingnya ketepatan dalam menegakkan diagnosa. Referensi berupa jurnal dan buku teks yang digunakan adalah sebanyak 14. Jurnal yang digunakan sebagai referensi dalam tulisan ini diterbitkan dalam kurun waktu 10 tahun terakhir.

\section{Hasil}

Proses keperawatan merupakan suatu sistem yang disusun secara sistematis dalam pemberian asuhan keperawatan. Dalam proses keperawatan, diagnosa merupakan tahap kedua setelah pengkajian. Perawat bertanggung jawab untuk merumuskan diagnosa dengan menggunakan data-data yang terkumpul selama proses pengkajian. Diagnosa merupakan dasar untuk menentukan intervensi keperawatan yang tepat dan berkulitas. Oleh karena itu, diagnosa keperawatan yang dirumuskan atau ditegakkan oleh perawat harus tepat. 


\section{Pembahasan}

Perawat merupakan salah satu tenaga kesehatan yang memiliki pern besar dalam merawat pasien. Dalam menjalankan perannya, perawat harus berfokus pada orientasi untuk menyembuhakn penyakit maupun meningkatkan atau mempertahankan kesehatan pasien. Untuk dapat mencapai hal itu, perawat harus bekerja sesuai standard. Perawat dapat bekerja mengikuti suatu sistem atau metode yang disebut dengan proses keperawatan. Proses keperawatan terdiri dari lima tahap, yaitu pengkajian, diagnosa, perencanaan, implementasi, dan evaluasi. Proses keperawatan dilakukan untuk membantu perawat menentukan intervensi keperawatan yang tepat.

Diagnosa merupakan salah satu tahap dalam proses keperawatan, yang dilakukan setelah pengkajian. Diagnosa keperawatan adalah proses menganalisis data yang didapatkan melalui proses pengkajian untuk menegakkan diagnosa. Sebelum merumuskan diagnosa, perawa memiliki tanggung jawab untuk mengenal atau mengidentifikasi masalah kesehatan klien. Untuk mengidentifikasi kebutuhan klien, perawat harus lebih dulu menentukan apakah masalah kesehatan pasien tersebut aktual atau potensial. Masalah kesehatan aktual adalah masalah ynag dialami atau dirasakan pasien, seperti gangguan pola tidur yang berhubungan dengan lingkungan yang bising. Sedangkan masalah kesehatan potensial atau beresiko mewaspadakan perawat pada pentingnya intervensi pencegahan (Gordon, 1994 di Potter \& Perry, 2005). Dalam tahap diagnosa, perawat berperan secara independen, artinya perawat dapat merumuskan sendiri diagnosanya, bertanggung jawab terhadap diagnosa yang dirumuskan, membedakan peran perawat dengan peran dokter, serta menunjukkan bahwa asuhan keperawatan tersebut bermutu, mempunyai kualitas, dan atas dasar pendidikan perawat.

\section{Penutup}

Diagnosa keperawatan adalah proses menganalisis data yang didapatkan melalui proses pengkajian untuk menegakkan diagnosa. Dalam merumuskan atau menegakkan diagnosa, perawat harus dapat melakukannya dengan tepat. Diagnosa yang tepat akan menjadi dasar dalam 
menentukan intervensi yang bermutu dan berkualitas.

\section{Referensi}

Ali, Z. (2001). Dasar-dasar keperawatan profesional. Jakarta: Penerbit EGC.

Apriyani, H. (2015). Identifikasi Diagnosis Keperawatan Pada Pasien di Ruang Paru Sebuah Rumah Sakit. Jurnal Keperawatan. 11(1): 107-111.

Astar, F. dkk. (2018). Pengaruh Pelayanan Asuhan Keperawatan Terhadap Kepuasan Pasien di Puskesmas Takalala Kabupaten Soppeng. Journal of Management. 1(2): 33-57.

Deswani. (2009). Proses Keperawatan dan Berpikir Kritis. Jakarta: Salemba Medika.

Haryanto. (2008). Konsep Dasar Keperawatan dengan Pemetaan Konsep (Concept Mapping). Jakarta: Salemba Medika.

Hastuti, W. \& Widiyaningsih. (2017). Aplikasi Concept Mapping Dalam Pemberian Asuhan Keperawatan di
Stase Maternitas. Jurnal Keperawatan dan Pemikiran Ilmiah. 3 (3): 19-26.

Herdman, T. H. \& Shigemi Kamitsuru. (2018). NANDA International Nursing Diagnoses: Definitions and Classification (2018-2020). Jakarta: EGC.

Lismidar, H. dkk. (1990). Proses Keperawatan. Jakarta: UI Press.

Maryam, Siti, dkk. (2006). Buku Ajar Berpikir Kritis dalam Proses Keperawatan. Jakarta: EGC.

Potter \& Perry. (2005). Buku Ajar Fundamental Keperawatan: Konsep, Proses, dan Praktik Edisi 4. Jakarta: EGC.

Simamora, R.H. (2009). Dokumentasi Proses Keperawatan. Jember: Jember University Press.

Simamora, R.H. (2010). Komunikasi dalam Keperawatan. Jember: Jember University Press.

Tarwoto \& Wartonah. (2012). Kebutuhan Dasar Manusia dan Proses 
Keperawatan. Jakarta: Salemba

Medika.

Vaughans, Bennita W. (2013).

Keperawatan Dasar. Yogyakarta:

Rapha Publishing. 